\title{
Conceptual Design and Simulation of an Unmanned Battery Exchangeable Electric Bus Management System
}

\author{
Han-Ur Kim ${ }^{\dagger} \cdot$ Jun-Seok Park ${ }^{++} \cdot$ Ha-Ryoung $\mathrm{Oh}^{++} \cdot$ Yeong-Rak Seong ${ }^{+++}$
}

\begin{abstract}
The exchangeable battery electric bus is an eco-friendly public transportation vehicle. Due to the technological limitation, however, it should repeatedly change batteries with charged ones. The unmanned battery exchangeable electric bus being studied in Korea can exchange batteries automatically by using a battery swapping system. In this paper, we propose an unmanned battery exchangeable electric bus management system. The proposed system provides two services: the bus information service and the battery change scheduling service. The bus information service is the existing traditional metropolitan area bus information systems, which inform bus passengers how long they should wait for the buses. Our second service assigns a low-battery bus, which needs to change the batteries, to the battery swapping system, which stores fully-charged batteries. To validate the proposed system, we model the system by using the DEVS formalism. The simulation result shows that the proposed system provides the services properly.
\end{abstract}

Keywords : Bus Information System, Electric Bus, DEVS, Unmanned Battery Exchangeable Electric Bus

\section{배터리 자동 교체형 전기버스 운영 시스템의 개념적 설계 및 시뮬레이션}

김 한 얼 $^{\dagger}$ 박 준 석 ${ }^{+\dagger} \cdot$ 오 하 령 ${ }^{+\dagger} \cdot$ 성 영 락 ${ }^{++}$

\begin{abstract}
요 약
배터리 교체형 전기버스는 친환경 공공교통 수단이다. 그러나 기술적 한계로 인하여, 이 버스는 소모된 배터리를 충전된 배터리로 반복해서 교체해야 한다. 현재 국내에서 연구 중인 배터리 자동 교체형 전기버스는 배터리 무인 자동교체소에서 자동으로 배터리를 교체할 수 있다. 본 논문에서는 배터리 자동 교체형 전기버스 운영 시스템을 제안한다. 제안하는 시스템은 두 가지 서비스를 제공한다. 첫째, 이 시스템은 버스 도 착 알림 서비스를 제공한다. 이 서비스는 기존 대도시에서 서비스 중인 버스정보시스템의 기능으로, 버스 승객들에게 버스를 얼마나 기다려야 하는지를 알려준다. 둘째, 배터리 교체 스케줄링 서비스를 제공한다. 이 서비스는 배터리 잔량이 얼마 남아있지 않거나 배터리 교체를 원하는 버스를 완충된 배터리를 저장하고 있는 배터리 무인 자동교체소로 할당하는 역할을 한다. 제안된 시스템을 검증하기 위해서 시스템을 DEVS 형식론으로 모델링하였다. 시뮬레이션 결과, 제안된 시스템은 위의 서비스들을 충실히 수행함을 알 수 있었다.
\end{abstract}

키워드 : 버스정보시스템, 전기버스, 이산사건 시뮬레이션, 배터리 자동 교체형 전기버스

\section{1. 서 론}

전 세계적으로 온실가스 배출에 대한 관심이 증가하고 있

※ 본 연구는 국토해양부의 교통체계효율화사업 일환으로 수행되었음(과제 번호 10PTSI-B056303-01).

※ 이 논문은 2013년 정부(교육인적자원부)의 재원으로 한국학술진흥재단의 지원을 받아 수행된 연구임(KRF-2013-31Z20130012993-B2013-0011).

† 준 회 원 : 국민대학교 전자공학부 석사

†† 정 회 원 : 국민대학교 전자공학부 교수

ㅎ† 종신회원 : 국민대학교 전자공학부 교수 논문접수: 2013년 10월 29일

수 정 일 : 1차 2014년 1월 6일, 2차 2014년 1월 9일

심사완료 : 2014년 1월 13 일

* Corresponding Author: Yeong-Rak Seong(yeong@kookmin.ac.kr)
으며 이에 대한 규제가 강화되고 있다. 2005년에 발효된 교 토의정서를 시작으로 탄소세, 온실가스 배출권 거래제와 같 은 제도가 마련되고 있으며 이러한 제도의 등장으로 무분별 한 온실가스 배출은 직접적인 경제적 손실로 이어진다[1]. 따라서 각 나라에서는 녹색신기술을 선점하려는 연구가 활 발히 진행되고 있다. 우리나라 교통 분야에서도 온실가스 배출을 줄이려는 연구가 이루어지고 있다. 그 중 하나가 전 기버스다.

배터리 자동 교체형 전기버스[2-3]는 국내에서 연구 중인 배터리 교체 방식의 전기버스이다. 이 버스는 차량 상부에 장착된 배터리로부터 전력을 얻어 주행한다. 이 배터리는 
정류장에 설치된 배터리 무인 자동교체소에서 완충된 배터 리로 교체가 가능하다. 버스가 정류장에서 정차하여 승객들 을 태우고 내릴 때, 배터리 교체소에서는 내부 에이전트 시 스템의 지시에 따라 로봇 팔을 이용하여 버스의 배터리를 빼내고 완충된 새 배터리를 장착해준다. 즉, 배터리 자동 교 체형 전기버스는 배터리 잔량이 부족할 시 배터리 교체소에 정차하여 방전된 배터리를 반납하고 완충된 배터리를 교체 받을 수 있다.

배터리 자동 교체형 전기버스의 원활한 운행을 위해 모든 정류장에 배터리 교체소가 설치되는 것이 바람직하지만 비 용 문제 때문에 어렵다. 따라서 배터리 자동 교체형 전기버 스 시스템은 소수의 배터리 교체소로 운영될 수밖에 없다. 이러한 경우 배터리 교체소 수에 비해 버스는 다수이므로 특정 배터리 교체소가 여러 대의 버스들에게 배터리 교체 요청을 받는 상황이 벌어질 수 있다. 그러므로 특정 배터리 교체소가 매우 혼잡하다면 버스를 주변의 한가한 다른 배터 리 교체소로 유도하는 것이 이러한 현상을 해결하는 좋은 방법이 된다. 이를 위해서는 배터리 교체소들의 배터리 교 체 작업 스케줄을 관리하면서 버스들로부터 배터리 교체 요 청들을 받아서 처리하는 배터리 자동 교체형 전기버스 운영 시스템이 필요하다. 이러한 배터리 자동 교체형 전기버스 운영 시스템에는 버스와의 통신 인프라가 반드시 포함되어 야한다. 버스마다 무선 통신 장치를 설치하는 것은 적지 않 은 비용이 소요되므로 기존에 설치된 통신 인프라를 활용하 는 방향으로 시스템을 설계하는 것이 바람직하다.

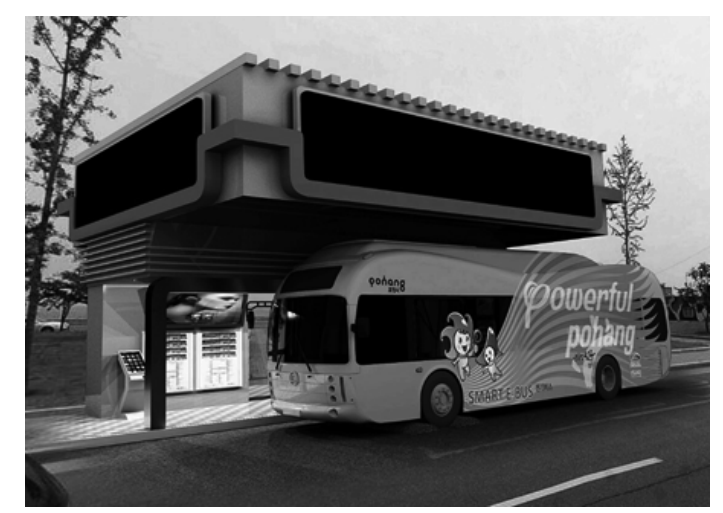

Fig. 1. The unmanned battery exchangeable electric bus and battery swapping system

본 논문에서는 현재 대도시에서 서비스 중인 버스정보시 스템의 통신 인프라를 활용한 배터리 자동 교체형 전기버스 운영 시스템을 제안한다. 제안하는 시스템은 기존에 서비스 중인 버스정보시스템의 기능을 그대로 수행하면서 추가되는 기능을 수행한다. 이 시스템은 크게 두 가지의 서비스를 제 공한다. 첫째, 이 시스템은 실시간으로 버스들의 위치정보를 수집하며 이를 토대로 정류장의 승객들에게 버스 도착 알림 서비스를 제공한다. 둘째, 이 시스템은 배터리 교체소들의 상태정보를 실시간으로 관리하며 버스가 배터리 교체를 요
청할 시 버스 위치와 배터리 교체소의 상태정보들을 참조하 여 가장 빠르게 교체를 받을 수 있는 배터리 교체소로 유도 하여 원활한 배터리 교체를 수행하게 하고 특정 배터리 교 체소에 여러 대의 버스가 몰리는 문제를 예방한다.

또한 본 논문은 제안한 시스템의 전체적인 구조를 제안하 고 각 시스템 요소들의 역할을 제시하는 것을 목표로 한다. 여기에 추가로 제안된 시스템의 통신 부하를 하위 프로토콜 의 오버헤드를 제외한 순수 데이터만을 가지고 추정해보고 자 한다.

마지막으로 본 논문에서는 제안된 시스템이 목표로 하는 기능들을 충실하게 수행할 수 있는지를 검증하기 위해서 제안 된 시스템을 Discrete Event System Specification (DEVS) 형식론을 이용하여 모델링한 후에 $\mathrm{DEVSim}^{++}$환경에서 시 뮬레이션 하였다.

본 논문의 구성은 다음과 같다. 2장에서는 기존의 버스정 보시스템에 대해서 알아본다. 3장에서는 본 논문에서 제안 하는 배터리 자동 교체형 전기버스 운영 시스템에 대하여 기술한다. 4장에서는 배터리 자동 교체형 전기버스 운영 시 스템에 대한 모델링 및 시뮬레이션을 소개하고 5장에서 결 론을 맺는다.

\section{2. 버스정보시스템}

이번 장에서는 기존의 버스정보시스템 (Bus Information System, BIS)에 대하여 살펴보고자 한다. 버스정보시스템 [4-6]이란, 버스와 정류장에 무선 송 - 수신기를 설치하여 버 스의 운행 상황을 실시간으로 파악하여 승객들에게 버스 도 착 예정 시간을 알리는 서비스를 제공한다. 또한 운전자에 게는 버스 간 배차 간격을 효율적으로 조절할 수 있도록 운 행정보를 제공하고 운영관리자에게는 버스 운행현황을 중앙 운영센터에서 실시간으로 알려준다.

버스정보시스템은 버스 단말, 정류장 단말, 운영센터로 구 성된다. 버스 단말은 서비스의 대상이 되는 각각의 버스마 다 설치되며 GPS를 이용하여 위치정보를 얻고 이 정보를 운영센터로 송신한다. 한편 운영센터는 각각의 버스 단말들 로부터 수신한 정보들을 종합하여 정류장 단말들로 보낸다. 정류장 단말은 정류장마다 설치되는 장치로서 운영센터로부 터 수신한 정보를 디스플레이 장치로 표출하여 버스 승객들 이 기다리는 버스들의 도착 예정시간을 알 수 있도록 한다.

\section{1 버스정보시스템의 통신 방식}

버스 단말과 운영센터 또한 운영센터와 정류장 단말 간 에는 통신망이 갖추어져야 한다. 운영센터와 정류장 단말 은 고정된 개체이기 때문에 유선 통신망을 구축하여 통신 할 수 있다. 그러나 버스 단말은 이동하는 개체이기 때문 에 반드시 무선 통신망을 구축하여 운영센터와 통신해야 한다. 버스정보시스템에서 사용하는 무선 통신 방식은 수 신 범위에 따라 단거리 통신망과 광역통신망으로 구분할 수 있다. 
단거리 통신망에는 대표적으로 비콘 (Beacon) 방식이 있 다[4]. 이 방식은 노변에 일정 거리마다 설치된 비콘을 통해 버스 단말이 정보를 전달하는 방식이다. 버스 단말로부터 정보를 전달받은 비콘은 유선으로 운영센터와 연결되어 버 스의 운행정보를 전달하게 된다. 이와 같은 단거리 통신망 으로 버스정보시스템을 운영하려면 버스 사업자가 모든 시 설물을 직접 설치하고 운영해야하므로 유지 보수비가 지속 적으로 발생한다.

광역통신망에는 대표적으로 $\mathrm{CDMA}$ 방식과 무선데이터 방 식이 있다. 무선데이터 방식은 898 900MHz와 938 940MHz 주파수를 사용하는 방식이다. CDMA망은 이미 기존에 이동 통신서비스를 위해 전국 곳곳에 구축되어있다. 따라서 버스 사업자가 광역통신망으로 버스정보시스템을 운영하려면 통 신사업자의 CDMA망을 임대하는 것이 바람직하다. CDMA 망을 임대하여 버스정보 시스템을 운영하면 별도의 시설 구 축 없이 통신 사업자에게 망 사용료를 지불하기만 하면 통 신망을 사용할 수 있고 유지·보수까지 해결되는 장점이 있 다. 그러나 임대망의 안정성과 신뢰성이 잘 보장되지 않으 면 문제가 발생할 수 있다.

\section{2 국내 버스정보시스템 현황}

국내 버스정보시스템 구축사업은 1995년 7월에 시작된 과 천시의 ITS 시범사업을 시초로 대전광역시, 전주시, 제주시 의 첨단교통모델도시 건설 사업을 통해 전국적인 사업 확장 의 기틀을 마련하여 특별시, 광역시, 수도권의 중소도시, 지 방의 교통거점도시들로 점차 확대되었다.

국내 버스정보시스템 도입 초기에는 단거리 통신망을 주 로 사용하였다. 그러나 최근에는 도시전체를 대상으로 하거 나 인접한 여러 도시를 연계하기 위해 광역 버스정보시스템 을 구축하는 경우가 많아 광역통신망이 많이 쓰이고 있다. 이러한 경향은 앞으로도 계속 지속될 것으로 보인다. 경기 도 버스정보시스템이 그 대표적인 예가 되겠다. Table 1은 현재 운영 중인 버스정보시스템들을 정리한 것이다[4-5].

Table 1. Contemporary bus information systems

\begin{tabular}{c|c|r}
\hline 구축도시 & 통신 방식 & 버스 대수 \\
\hline 서울시 & 무선데이터 방식 & 7500 여대 \\
\hline 부천시 & 비콘 방식 & 700 여대 \\
\hline 광주시 & CDMA 방식 & 900 여대 \\
\hline 인천시 & 무선데이터 방식 & 1900 여대 \\
\hline 시흥시 & 비콘 방식 & 50 여대 \\
\hline 안산시 & CDMA+무선데이터 방식 & 400 여대 \\
\hline 대구시 & CDMA 방식 & 1600 여대 \\
\hline 대전시 & DSRC 방식 & 960 여대 \\
\hline 울산시 & 무선데이터+비콘 방식 & 570 여대 \\
\hline 안양시 & 무선데이터 방식 & 1720 여대 \\
\hline 군포시 & 비콘 방식 & 300 여대 \\
\hline 수원시 & CDMA 방식 & 181 여대 \\
\hline 원주시 & CDMA 방식 & 200 여대 \\
\hline 고양시 & CDMA 방식 & 540 여대 \\
\hline & &
\end{tabular}

\section{3. 배터리 자동 교체형 전기버스 운영 시스템}

본 논문에서 제안하는 배터리 자동 교체형 전기버스 운 영 시스템은 새로운 통신 인프라 구축 없이 기존의 통신 인프라로도 버스 도착 알림 서비스와 배터리 자동 교체형 전기버스의 배터리 교체 스케줄링 서비스를 제공할 수 있 도록 설계하였다. 본 장에서는 먼저 시스템의 전체적인 구 조 및 구성요소들의 역할에 대해서 설명하고, 다음으로 배 터리 자동 교체형 전기버스 운영 시스템의 두 가지 주요 기능을 위한 구성 요소들의 동작을 설명한다. 마지막으로 제안된 시스템의 통신량을 서울시 버스 시스템을 기준으로 분석한다.

\section{1 전체 구조}

배터리 자동 교체형 전기버스 운영 시스템은 기본적으로 버스 단말 (Bus Terminal, BT), 배터리 교체 시스템 단말 (Battery Swapping System Terminal, ST), 버스 정보 표출 시스템 단말 (Bus User Terminal, UT), 서버 (Server)로 구 성된다. 서버는 전체 시스템을 제어하는 장치로서, 시스템의 규모와 부하에 따라 하나 이상 설치될 수 있다. 하지만 본 논문에서는 시스템의 전체적인 동작을 간략히 설명하기 위 해 하나의 서버를 설치한 상황을 가정하여 시스템 동작을 기술한다. 이외에 버스에는 하나의 BT, 배터리 교체소에는 하나의 ST, 정류장에는 하나의 UT가 설치된다. 즉, 배터리 자동 교체형 전기버스 운영 시스템에서는 하나 이상의 서버 와 다수의 $\mathrm{BT}, \mathrm{ST}, \mathrm{UT}$ 로 구성된다.

이들의 통신관계를 살펴보면 우선 서버는 전체 시스템을 제어하기 위해 $\mathrm{BT}, \mathrm{ST}, \mathrm{UT}$ 와 통신한다. $\mathrm{BT}$ 는 평상시에는 버스 위치정보 전달을 위해 서버와 통신하며 배터리 교체 작업 시에는 ST와도 통신한다. ST는 배터리 교체 작업을 위해 $\mathrm{BT}$ 와 통신하며 배터리 교체소의 상태정보를 제공하기 위해 서버와도 통신한다. UT는 버스 도착 정보를 전송받기 위해 서버와 통신한다. Fig. 2는 배터리 자동 교체형 전기버 스 운영 시스템의 구성요소들 간의 통신관계를 도식화한 그 림이다.

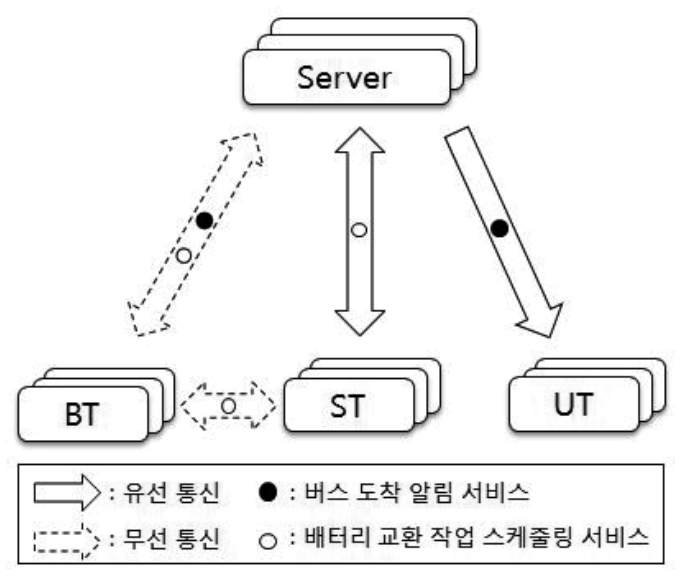

Fig. 2. Communication among components 
시스템 구성 요소들의 통신방식을 살펴보면 서버, ST, $\mathrm{UT}$ 와 같은 고정된 시설에 설치되는 장치들의 경우에는 유· 무선 통신방식이 모두 가능하다. 하지만 BT 같은 이동하는 버스에 설치되는 장치는 반드시 무선 통신방식이 적용되어 야 한다.

\section{2 버스 도착 알림 서비스}

버스 도착 알림 서비스는 곧 도착할 버스의 도착 예정 시 간과 현재 위치를 정류장의 디스플레이 장치를 통해 표출해 줌으로써 정류장에서 버스를 기다리는 승객들에게 편의를 제공하는 기능이다. 이 기능은 기존 버스정보시스템에서도 제공되었던 기능이며, 배터리 자동 교체형 전기버스 운영 시스템에서도 동일하게 제공한다.

Fig. 3은 버스 도착 알림 서비스를 제공하기 위해 배터리 자동 교체형 전기버스 운영 시스템내의 구성 요소들이 어떻 게 동작하는지를 도식화한 것이다. 그림에서 나타난 바와 같이 이 서비스를 위해서는 $\mathrm{BT}$, 서버, $\mathrm{UT}$ 가 동작해야 한다. 이 중에서 $\mathrm{BT}$ 와 서버는 앞으로 설명할 배터리 교체 스케줄 링 서비스에서도 동작하지만, UT는 오직 버스 도착 알림 서비스를 위해서만 동작한다.

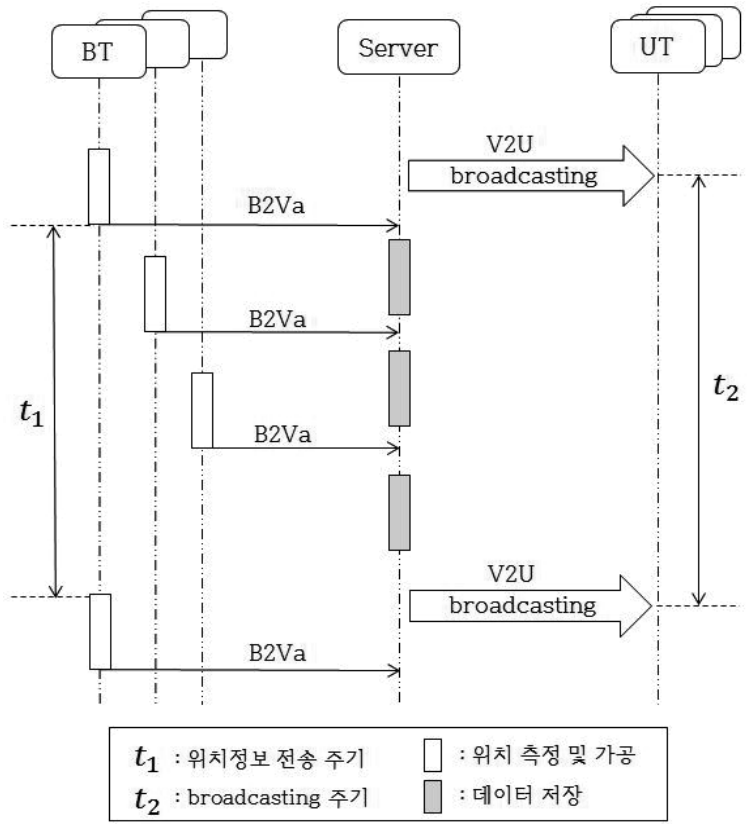

Fig. 3. Interaction sequence among components for the bus arrival notification service

$\mathrm{BT}$ 는 버스 도착 알림 서비스를 위해서 주기적으로 버스 노선도 상에서의 자신의 위치를 $\mathrm{B} 2 \mathrm{Va}$ (Bus to serVer type-a) 메시지를 전송하여 서버에게 보고한다. 이를 위해서 $\mathrm{BT}$ 는 버스 노선도에 대한 데이터를 미리 저장하고 있으면 서, 버스에 장착된 $\mathrm{GPS}$ 로부터 얻은 위경도 정보를 버스 노 선도 상의 한 점으로 매핑 (mapping)하는 작업을 수행한다. $\mathrm{BT}$ 가 위경도 정보 대신 버스 노선도상의 좌표로 가공하여
전송하는 것은 통신되는 데이터양을 줄이고 서버의 부하를 경감시키기 위한 것이다.

서버는 버스 도착 알림 서비스를 위해서 서비스 구역 내 의 운행 중인 모든 버스의 $\mathrm{BT}$ 로부터 전송된 $\mathrm{B} 2 \mathrm{Va}$ 메시지에 포함된 버스들의 위치정보를 취합하여 주기적으로 UT들에게 $\mathrm{V} 2 \mathrm{U}$ (serVer to User) 메시지를 브로드캐스팅 (broadcasting) 하는 역할을 한다. 수집된 버스들의 위치 정보는 앞으로 설 명할 배터리 교체 스케줄링 서비스에서도 활용된다.

$\mathrm{UT}$ 는 서버가 브로드캐스팅한 V2U 메시지 내의 버스 위 치정보 데이터로부터 자신의 정류장에 해당하는 위치정보만 을 추출하여 디스플레이하는 역할을 한다. 서버가 각각의 $\mathrm{UT}$ 에게 개별적으로 맞춤정보를 보내는 대신 전체 정보를 브로드캐스팅하고 $\mathrm{UT}$ 가 그것으로부터 필요한 정보만을 추 출하도록 하는 것은 서버에서 전송되는 데이터양과 서버의 연산량을 줄이기 위한 것이다.

다음으로 위와 같은 방식으로 동작하기 위해서 필요한 통 신량의 크기에 대해 고찰해보자. 첫 번째로 $\mathrm{BT}$ 에서 서버로 전송되는 B2Va 메시지로 인한 통신량을 살펴보자. Fig. 4는 $\mathrm{B} 2 \mathrm{Va}$ 메시지 구조를 도식화한 것이며 괄호안의 숫자는 각 각의 필드를 나타내는 비트 수이다. $\mathrm{B} 2 \mathrm{Va}$ 메시지는 메시지 타입 (Type), 발생 시간 (Time), 버스의 노선 번호 (Route), 버스 $\mathrm{ID}(\mathrm{BID})$, 노선 상의 좌표 $(\mathrm{Loc})$ 필드로 구성된다. 메 시지 타입 필드는 배터리 자동 교체형 전기버스 운영 시스 템에서 사용되는 메시지들을 구분하기 위한 것이다. 제안된 시스템에서는 총 12 가지 종류의 메시지가 사용되고 있으며, 각 메시지 종류를 구분하기 위해 메시지 타입 필드를 4 비 트로 표현하였다. 메시지 발생시간은 32 비트로 표현하였으 며 기준 시각 이후 몇 초가 지났는지를 나타낸다. 버스 노 선 번호는 10 비트로 표현하였다. 버스 $\mathrm{ID}$ 는 같은 노선에 해당하는 버스를 식별하기 위한 값으로 6 비트로 표현하였 다. 버스의 위치를 나타내는 노선 상의 좌표는 8 비트로 표 현하였다. 그러므로 $\mathrm{B} 2 \mathrm{Va}$ 메시지는 60 비트의 고정된 길이 를 가진다. $\mathrm{BT}$ 의 위치정보 전송주기를 $\mathrm{T}_{1}$, 하나의 무선기지 국 내의 $\mathrm{BT}$ 의 수를 $\mathrm{n}_{1}$ 이라고 했을 때 서버가 받는 초당 $\mathrm{B} 2 \mathrm{Va}$ 메시지의 초당 비트 수는

$$
\frac{60 \mathrm{n}_{1}}{\mathrm{~T}_{1}}
$$

비트가 된다.

B2Va
\begin{tabular}{|c|c|c|c|c|}
\hline $\begin{array}{c}\text { Type } \\
(4)\end{array}$ & $\begin{array}{c}\text { Time } \\
(32)\end{array}$ & $\begin{array}{c}\text { Route } \\
(10)\end{array}$ & $\begin{array}{c}\text { BID } \\
(6)\end{array}$ & $\begin{array}{c}\text { Loc } \\
(8)\end{array}$ \\
\hline
\end{tabular}

Fig. 4. B2Va message

다음으로 서버에서 각 정류장의 UT로 브로드캐스팅하는 $\mathrm{V} 2 \mathrm{U}$ 메시지 구조는 Fig. 5와 같다. $\mathrm{V} 2 \mathrm{U}$ 메시지는 메시지 타입 (Type), 발생 시간 (Time), 버스의 노선번호 (Route), 
버스 ID (BID), 노선 상의 좌표 (Loc), EOP (End of Packet) 필드로 구성되며 가변 길이를 가진다. 여러 대의 버스 위치 정보를 한 메시지로 전송하기 위해 노선번호, 버스 $\mathrm{ID}$, 노선 상의 좌표를 나타내는 필드들이 그 시각에 운행 중인 버스 의 수 $\mathrm{n} 2$ 번만큼 반복된다. 마지막에는 메시지의 끝을 알리는 $\mathrm{EOP}$ 가 1 바이트 들어간다. 이것들을 종합해보면 서버에서 $\mathrm{UT}$ 로 브로드캐스팅하는 $\mathrm{V} 2 \mathrm{U}$ 메시지의 길이는 $44+24 \mathrm{n} 2$ 비 트가 된다.

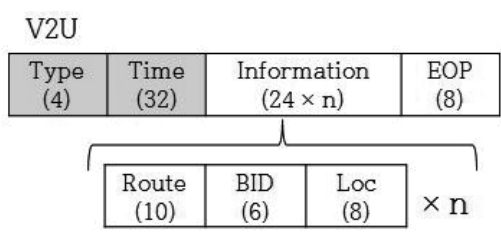

Fig. 5. V2U message

반면, 서버에서 각 정류장으로 브로드캐스팅하는 주기를 $\mathrm{T}_{2}$ 라고 했을 때 서버가 보내는 초당 메시지 비트 수는

$$
\frac{44+24 \mathrm{n}_{2}}{\mathrm{~T}_{2}}
$$

비트가 된다. 일반적으로 하나의 배터리 자동 교체형 전기 버스 운영 시스템 내에서 동작 중인 버스의 수 $\mathrm{n}_{2}$ 은 수백 혹은 수천에 달하므로 식 (2)에서 상수 44는 무시할 수 있 다. 그러므로 버스 도착 알림 서비스에 의한 초당 메시지 송수신량은

$$
\frac{60 \mathrm{n}_{1}}{\mathrm{~T}_{1}}+\frac{24 \mathrm{n}_{2}}{\mathrm{~T}_{2}}
$$

비트가 된다.

\section{3 배터리 교체 작업 스케줄링 서비스}

배터리 교체 작업 스케줄링 서비스는 배터리 자동 교체형 전기버스가 원활하게 배터리 교체를 받을 수 있도록 적절한 배터리 교체소를 배정해 주는 서비스다. 이 서비스는 배터 리 교체 작업을 배터리 교체소들에게 적절히 분배하여 여러 대의 버스들이 특정 배터리 교체소에 몰리게 되는 현상을 방지한다. Fig. 6은 배터리 교체 작업 스케줄링 서비스를 위 해 배터리 자동 교체형 전기버스 운영 시스템내의 구성 요 소들이 어떻게 동작하는지를 도식화한 것이다. 그림에서 나 타난 바와 같이 이 서비스를 위해서는 $\mathrm{BT}$, 서버, ST가 동 작해야한다. 또한 사전에 서버가 버스들의 위치정보 현황이 파악되어야 원활한 스케줄링 서비스가 가능하다.

배터리 교체 작업 스케줄링 서비스는 요청, 진입, 교체, 출고과정으로 나뉜다. 요청과정에서는 $\mathrm{BT}$ 가 버스의 배터리 가 기준치 미만으로 떨어진 것을 감지하여 운전자에게 경고

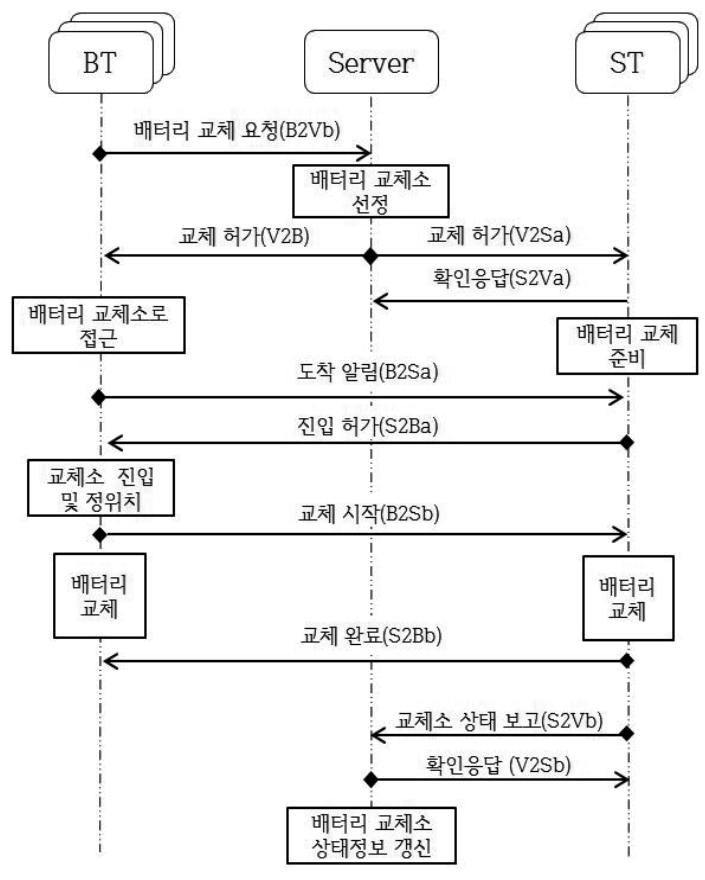

Fig. 6. Interaction sequence among components for the battery exchange scheduling service

하여 운전자가 배터리 교체 신청을 하도록 유도한다. 이후 $\mathrm{BT}$ 는 운전자의 지시에 따라 배터리 교체를 신청하는 $\mathrm{B} 2 \mathrm{Vb}$ (Bus to serVer type-b) 메시지를 서버로 전송한다. B2Vb 메시지를 받은 서버는 자신이 가지고 있는 버스 위치 현황 과 배터리 교체소의 상태정보를 이용하여 가장 빠르게 배터 리 교체를 받을 수 있는 배터리 교체소를 선정하고 버스에 게 V2B (serVer to Bus) 메시지를 전송하여 알려준다. 이와 동시에 서버는 배정된 배터리 교체소의 ST에게도 $\mathrm{V} 2 \mathrm{Sa}$ (serVer to Swapping system type-a) 메시지를 보내 배터 리 교체소가 배터리 교체 준비 상태를 갖출 수 있도록 한다. 이후 배터리 교체소로부터 $\mathrm{V} 2 \mathrm{Sa}$ 메시지 수신이 잘 되었음 을 알리는 확인응답으로 S2Va (Swapping system to serVer type-a) 메시지를 받는다.

다음은 진입과정이다. 버스가 지정된 배터리 교체소 앞에 도착하게 되면 $\mathrm{BT}$ 는 $\mathrm{B} 2 \mathrm{Sa}$ (Bus to Swapping system type-a) 메시지를 보내어 자신의 도착을 알리고 대기하고 있던 ST는 S2Ba (Swapping system to Bus type-a) 메시 지를 내줌으로써 버스를 배터리 교체소 내부로 진입시킨다. 만일 배터리 교체소가 다른 버스의 배터리 교체 작업을 진 행 중이었다면 ST는 $\mathrm{S} 2 \mathrm{Ba}$ 메시지 전송을 보류함으로써 도 착한 버스를 대기시킨다.

진입과정이 끝나면 교체과정이 이루어진다. ST에게서 $\mathrm{S} 2 \mathrm{Ba}$ 메시지를 받은 버스가 배터리 교체소 내부에 정위치 하고 운전자의 조작에 의해 BT가 B2Sb (Bus to Swapping system type-b) 메시지를 전송하면 배터리 교체가 시작된 다. 이때 버스의 제어권이 ST로 넘어가게 되며 ST가 배터 리 교체를 주도하게 된다. 
배터리 교체가 완료되면 ST는 S2Bb (Swapping system to Bus type-b) 메시지를 BT에게 전송하여 배터리 교체가 완료되었음을 알리며 버스의 제어권을 돌려주고 버스를 배 터리 교체소 밖으로 출고시킨다. 이와 동시에 서버에게 S2Vb (Swapping system to serVer type-b) 메시지를 전송 하여 서버에게 배터리 교체소의 상태정보를 전달한다. 이후 서버는 전달받은 배터리 교체소의 상태 정보를 갱신하고 V2Sb (serVer to Swapping system type-b) 메시지를 전송 하여 데이터 수신이 정상적으로 되었음을 ST에게 알려준다. 이 과정을 마지막으로 버스의 배터리 교체과정이 종료된다.

다음으로 위와 같은 방식으로 동작하기 위해서 필요한 통 신량의 크기에 대해 고찰해보자. Fig. 7은 B2Vb 메시지 구 조를 도식화한 것이다. B2Vb 메시지는 메시지 타입 (Type), 발생 시간 (Time), 버스의 노선 번호 (Route), 버스 ID (BID) 필드로 구성된다. 각 필드는 앞 절에서 소개한 비트 수와 동일하며, 이에 따라 $\mathrm{B} 2 \mathrm{Vb}$ 메시지는 52 비트의 크기 를 갖는다. S2Vb 메시지 구조는 Fig. 8과 같으며 Fig. 10의 메시지 구조에서 배터리 교체소에서 보관중인 완충된 배터 리 수 $(\mathrm{nBatt})$ 를 나타내는 필드가 추가된 형태이며 69 비트 의 크기를 갖는다. V2Sb, S2Va 메시지 구조는 Fig. 9와 같 으며 메시지 타입 (Type), 발생 시간 (Time), 배터리 교체 소 $\mathrm{ID}(\mathrm{SID})$ 필드로 구성되며 49 비트의 크기를 갖는다. 이 외에 V2B, V2Sa, B2Sa, B2Sb, S2Ba, S2Bb 메시지는 Fig. 10 과 같은 구조를 가지며 메시지 타입 (Type), 버스의 노선 번호 (Route), 버스 ID (BID), 배터리 교체소 ID (SID) 필드 로 구성되며 65 비트의 크기를 갖는다.

\section{$\mathrm{B} 2 \mathrm{Vb}$}

\begin{tabular}{|c|c|c|c|}
\hline $\begin{array}{c}\text { Type } \\
(4)\end{array}$ & $\begin{array}{c}\text { Time } \\
(32)\end{array}$ & $\begin{array}{c}\text { Route } \\
(10)\end{array}$ & $\begin{array}{c}\text { BID } \\
(6)\end{array}$ \\
\hline
\end{tabular}

Fig. 7. B2Vb message

$\mathrm{S} 2 \mathrm{Vb}$

\begin{tabular}{|c|c|c|c|c|c|}
\hline Type & $\begin{array}{c}\text { Time } \\
(4)\end{array}$ & $\begin{array}{c}\text { Route } \\
(32)\end{array}$ & $\begin{array}{c}\text { BID } \\
(10)\end{array}$ & $\begin{array}{c}\text { SID } \\
(6)\end{array}$ & $\begin{array}{c}\text { nBatt } \\
(13)\end{array}$ \\
\hline
\end{tabular}

Fig. 8. S2Vb message

V2Sb, S2Va

\begin{tabular}{|c|c|c|}
\hline $\begin{array}{c}\text { Type } \\
(4)\end{array}$ & $\begin{array}{c}\text { Time } \\
(32)\end{array}$ & SID \\
$(13)$ \\
\hline
\end{tabular}

Fig. 9. V2Sb and S2Va messages

V2B, V2Sa, B2Sa, B2Sb, S2Ba, S2Bb

\begin{tabular}{|c|c|c|c|c|}
\hline $\begin{array}{c}\text { Type } \\
(4)\end{array}$ & $\begin{array}{c}\text { Time } \\
(32)\end{array}$ & $\begin{array}{c}\text { Route } \\
(10)\end{array}$ & $\begin{array}{c}\text { BID } \\
(6)\end{array}$ & $\begin{array}{c}\text { SID } \\
(13)\end{array}$ \\
\hline
\end{tabular}

Fig. 10. Other messages
여기서 버스의 배터리 교체 주기를 $\mathrm{T}_{3}$, 시스템 내에서 운 행되는 버스 수를 $\mathrm{n}_{3}$ 이라고 했을 때 $\mathrm{BT}$, 서버, ST간의 초 당 메시지 송수신량은

$$
\frac{52+(65 \times 6)+(49 \times 2)+69}{\mathrm{~T}_{3}} \times \mathrm{n}_{3}=\frac{609 \times \mathrm{n}_{3}}{\mathrm{~T}_{3}}
$$

비트가 된다.

\section{4 통신량에 대한 고찰}

앞서 소개한 두 가지 서비스의 대략적인 통신부하를 추정 하기 위해 하위 프로토콜 계층의 오버헤드를 제외한 순수 통신량의 크기를 예측해보자. 먼저 식 (3)을 전국에서 버스 가 많이 밀집되는 지역 중에 한 곳인 서울역을 기준으로 계 산해보자. 가장 교통이 혼잡한 시간대에는 서울시에 등록된 7500 대의 버스가 같은 $\mathrm{CDMA}$ 망 내에서 모두 운행되며 $\left(\mathrm{n}_{2}=7500\right)$, 서울역을 중심으로 $1 \mathrm{~km}$ 반경 내에는 150 개의 버스 노선이 있고 각 노선별로 버스가 2대씩 이 지역 내에 운행 중에 있다고 $\left(\mathrm{n}_{1}=300\right)$ 하자. 또한 BT에서 서버로 데이 터를 전송하는 주기 $\mathrm{T}_{1}$ 은 10 초, 서버에서 $\mathrm{UT}$ 로 데이터를 전송하는 주기 $\mathrm{T} 2$ 는 20 초로 가정하자. 그러면 식 (3)에 의해 버스 도착 알림 서비스의 초당 메시지 송수신량은 10.8 kbps가 된다.

다음으로 식 (4)를 이용하여 배터리 교체 작업 스케줄링 에 필요한 통신량의 크기를 계산해보자. 계산에 앞서 버스 는 완충된 배터리로 $20 \mathrm{~km}$ 의 거리를 평균속도 $20 \mathrm{~km} / \mathrm{h}$ 로 주행하며 배터리 잔량이 $20 \%$ 미만일 때마다 배터리 교체 요 청을 한다고 가정하였다. 이에 따라 버스는 시속 $20 \mathrm{~km} / \mathrm{h}$ 로 1 시간동안 달릴 수 있으며 약 48 분에 배터리 잔량이 $20 \%$ 미 만으로 떨어지게 된다. 즉, 48 분 $\left(\mathrm{T}_{3}=48 \times 60 \mathrm{sec}\right)$ 마다 버스는 서버에게 배터리 교체요청을 하게 된다. 물론 이 주기는 버 스의 정차시간까지 고려한다면 더 늘어날 것이다. 또한 최 악의 경우를 고려하여 서울시에 등록된 7500 대 $\left(\mathrm{n}_{2}=7500\right)$ 의 버스가 전부 배터리 교체 요청을 한다고 가정하면 식 (4)에 의해 배터리 교체 작업 스케줄링 서비스를 위한 초당 메시 지 전송량은 $1.6 \mathrm{kbps}$ 가 된다.

식 (3)과 식 (4)에 의해 버스 도착 알림 서비스와 배터리 교체 작업 스케줄링 서비스의 초당 메시지 전송량은

$$
\frac{60 \mathrm{n}_{1}}{\mathrm{~T}_{1}}+\frac{24 \mathrm{n}_{2}}{\mathrm{~T}_{2}}+\frac{609 \mathrm{n}_{3}}{\mathrm{~T}_{3}}
$$

비트가 된다. 식 (5)에 앞서 구한 값들을 대입해보면 두 가 지 서비스를 위해 필요한 초당 메시지 전송률은 $12.4 \mathrm{kbps}$ 가 된다. 이 정도의 통신량은 $\mathrm{CDMA}$ (최대 $144 \mathrm{kbps}$ )가 충 분히 감당할 수 있는 양이다. 또한 경우에 따라서는 서버에 서 정류장의 UT로의 통신 혹은 서버에서 ST로의 통신을 유선 통신망을 이용할 수도 있으므로 $\mathrm{CDMA}$ 망의 부하를 더 감소시킬 수 있다. 이 예제에서 사용된 파라미터 값들은 매 
우 극단적으로 통신량이 많이 발생하는 경우를 가정한 것이 다. 따라서 배터리 자동 교체형 전기버스 운영 시스템의 두 서비스가 기존 통신 인프라에서도 문제없이 구현이 가능함 을 쉽게 예상할 수 있다.

\section{4. 모델링 및 시뮬레이션}

본 장에서는 앞 장에서 제안된 배터리 자동 교체형 전기버 스 운영 시스템 기능들을 검증하기 위해 배터리 자동 교체형 전기버스 운영 시스템을 Discrete Event System Specification (DEVS) 형식론[7]을 기반으로 모델링하였다. DEVS 형식론 에서는 이산사건 시스템을 계층화 및 모듈화된 형태로 기술 한다. DEVS 형식론에서는 두 가지 종류의 모델이 있다. 원 소형 (Atomic) DEVS 모델은 기본적인 구성요소들의 동작 을 기술하는 데에 비하여, 결합형 (Coupled) DEVS 모델은 여러 구성요소들을 결합시켜 보다 큰 크기의 새로운 구성요 소를 만드는 것을 기술한다. DEVS 모델은 입력포트와 출력 포트를 통해서 다른 모델들과 상호 작용한다. DEVS 모델의 입력 포트를 통해서 다른 모델들로부터 입력을 전달받는 것 을 외부사건이라고 하며, 모델 스스로가 상태를 바꿀 시간 이 되었음을 통고받는 것을 내부사건이라고 한다. 내부사건 을 처리하는 과정에서는 출력이 발생하며 이것은 출력포트 를 통해서 그 포트에 연결된 다른 모델들에게 전달된다. $\mathrm{DEVS}$ 형식론에 대한 보다 자세한 내용은 [7]을 참조하라.

\section{1 가정}

본 논문에서는 무선 통신망에 대해서 다음 두 가지를 가 정하였다. 첫째, 배터리 자동 교체형 전기버스 운영 시스템 이 커버하는 전 지역에서 배터리 자동 교체형 전기버스 운 영 시스템의 모든 구성 요소들 간에는 항상 통신이 가능한 것으로 가정하였다.

둘째, 무선 통신 망의 속도가 매우 빨라서 각종 통신에 소요되는 시간은 무시할 수 있을 정도로 작은 것으로 가정하 였다. 실제 무선 통신 시간은 정도의 차이는 있으나 상당히 큰 값이다. 하지만 버스의 운행 속도에 비하면 통신 속도는 매우 빠르며, 앞서 3장에서 각 서비스별 통신량을 분석한 결 과에 따르면 이 가정들이 쉽게 만족된다고 볼 수 있다.

셋째, 버스가 배터리 교체를 요청했을 때 항상 $20 \mathrm{Km}$ 이내 에 완충배터리를 보유한 배터리 교체소가 1 개 이상 존재한 다고 가정하였다.

\section{2 전체 모델의 구성}

Fig. 11은 배터리 자동 교체형 전기버스 운영 시스템 모 델의 계층적인 구조를 나타낸 것이다. 트리의 종단에 위치 한 모델들은 원소형 DEVS 모델들로, 트리의 내부에 위치한 모델들은 결합형 $\mathrm{DEVS}$ 모델들로 기술된다. 전체 모델 EBUS_SYS는 크게 배터리 자동 교체형 전기버스 시스템의 서버를 나타내는 SERVER 모델, 버스들의 집합을 나타내는 BUSES 모델, 배터리 교체소들의 집합을 나타내는 SWAPS
모델, 정류장들의 집합을 나타내는 STOPS 모델로 구성된다. 또한 BUSES 모델은 다수의 BUS 모델들로, SWAPS 모델은 다수의 SWAP 모델들로, STOPS 모델은 다수의 STOP 모델 들로 구성된다. 앞서 무선 통신에 대한 가정에 의해 배터리 자동 교체형 전기버스 운영 시스템내의 구성 요소들은 항상 다른 구성 요소와 시간 지연 없이 통신할 수 있으므로 모델 링 시에는 통신에 대한 내용을 포함하지 않았다.
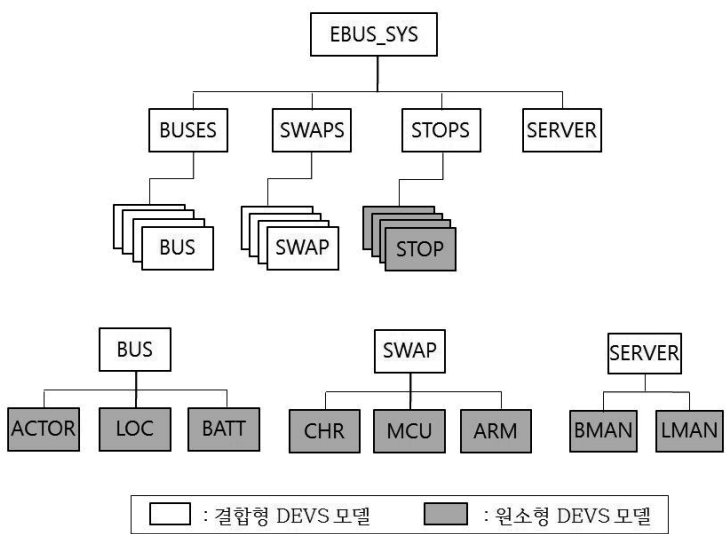

Fig. 11. Hierarchy of DEVS models

BUS 모델은 하나의 BT에 대응되는 모델로서 버스 운행 의 시작과 종료를 나타내는 ACTOR 모델, 버스의 위치정보 를 주기적으로 전송하는 $\mathrm{LOC}$ 모델, 버스의 배터리 교체 관 련 작업들을 처리하는 BATT 모델들로 구성된다. Fig. 12는 BUS 모델을 도식화한 것이다.

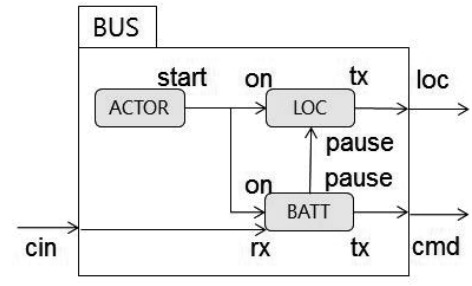

Fig. 12. BUS mode

SWAP 모델은 하나의 ST에 대응되는 모델로서 배터리 충전 장치를 제어하는 $\mathrm{CHR}$ 모델, 통신과 명령어 처리를 담 당하는 MCU 모델, 배터리 교체 장치를 제어하는 ARM 모 델들로 구성된다. Fig. 13은 SWAP 모델을 도식화한 것이다.

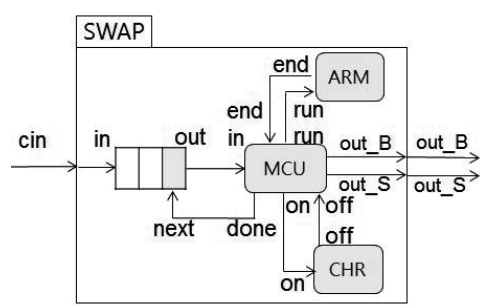

Fig. 13. SWAP model 
SERVER 모델은 하나의 서버에 대응되는 모델로서 위치 정보를 관리하는 LMAN 모델, 배터리 교체 관련 작업을 스 케줄링 해주는 BMAN 모델로 구성된다. Fig. 14는 SERVER 모델을 도식화한 것이다.

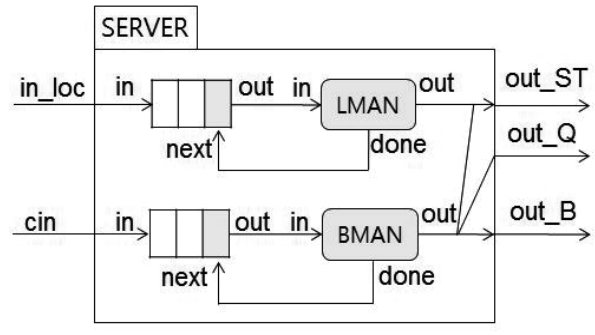

Fig. 14. SERVER model

4.3 버스 도착 알림 서비스의 모델링

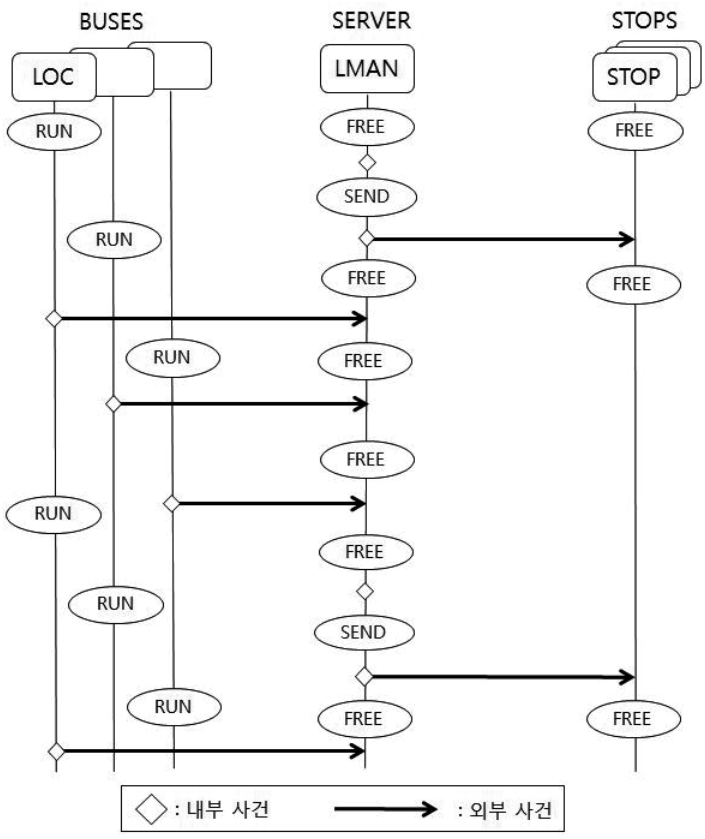

Fig. 15. Interaction sequence among DEVS models for the bus arrival notification service

본 절에서는 3.2절에서 설계된 버스 도착 알림 서비스에 대한 DEVS 모델에 대해 간략하게 설명한다. Fig. 15는 앞 서 Fig. 3에서 제시된 버스 도착 알림 서비스를 위한 구성 요소들 간의 상호 작용도를 $\mathrm{DEVS}$ 모델들 간의 상호 작용 도로 변환하여 나타낸 것이다. Fig. 3의 BT, Server, UT가 Fig. 15에서는 LOC, LMAN, STOP 모델로 바뀌어 있으며 Fig. 3의 메시지의 통신이 Fig. 15에서는 DEVS의 외부사건 으로 변환되었다. $\mathrm{LOC}$ 모델은 $\mathrm{BT}$ 의 기능 중에서 $\mathrm{GPS}$ 로부 터 위경도 정보를 얻어 노선좌표에 맞게 가공한 후 서버에 전송하는 동작을 모델링한 것이다. LOC 모델은 주기적으로 내부사건을 처리해서 출력을 발생시키며 이것들은 LMAN 모델의 입력포트로 전달된다. LMAN 모델은 서버의 기능 중
에서 BT로부터 수신한 위치정보를 수집하고 주기적으로 $\mathrm{UT}$ 들에게 브로드캐스팅하는 동작을 모델링한 것이다 LMAN 모델은 LOC 모델에 의해 외부사건이 들어올 때마다

\begin{tabular}{|c|c|}
\hline $\begin{array}{l}\text { [BUS] } \\
\text { 운행 } \\
\text { 시작 }\end{array}$ & $\begin{array}{l}\text { BUSO_ACTOR OutPut } \\
\text { BUSO_ACTOR:OFF sends (TYPe:_ON) @STOPrt:1 } \\
\text { \#\#(BUSO) POWER ON! @1sec }\end{array}$ \\
\hline$V$ & $\vdots$ \\
\hline $\begin{array}{l}\text { [BUS] } \\
\text { 위치정보 } \\
\text { 전송 }\end{array}$ & 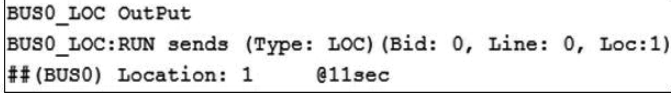 \\
\hline$V$ & $:$ \\
\hline $\begin{array}{l}\text { [SERVER] } \\
\text { 위치정보 } \\
\text { 수집 }\end{array}$ & $\begin{array}{l}\text { SERVER_LMAN: FREE receives (TYPe: LOC) ein: } 11 \\
\text { SERVER_LMAN OutPut } \\
\text { SERVER_LMAN:UPDATE sends (TYPe: DONE) edone: } 11\end{array}$ \\
\hline 7 & $\vdots$ \\
\hline $\begin{array}{l}\text { [SERVER] } \\
\text { 위치정보 } \\
\text { 브로드 } \\
\text { 캐스팅 }\end{array}$ & $\begin{array}{l}\text { TIMER OutPut } \\
\text { TIMER: ON sends (TYpe: ALARM) @alarm: } 16 \\
\text { SERVER_LMAN:FREE receives (TYPe: ALARM) Calarm: } 16 \\
\text { SERVER_LMAN OutPut } \\
\text { SERVER_LMAN:SEND sends (TYpe: LOC) @out_ST: } 17\end{array}$ \\
\hline 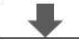 & $\vdots$ \\
\hline $\begin{array}{c}\text { [STOP] } \\
\text { 위치 } \\
\text { 정보 } \\
\text { 수신 }\end{array}$ & $\begin{array}{l}\text { STOP1: FREE receives (TYPe: LOC) @in: } 17 \\
\text { STOP3: FREE receives (TYPe: LOC) @in: } 17 \\
\text { STOP1 OutPut } \\
\text { STOP1: UPDATE sends DONE @done: } 18 \\
\text { STOP3 OutPut } \\
\text { STOP3: UPDATE sends DONE @done: } 18\end{array}$ \\
\hline
\end{tabular}

Fig. 16. Simulation logs of bus arrival notification service

\begin{tabular}{|c|c|}
\hline $\begin{array}{c}\text { 배터리 } \\
\text { 교체 요청 } \\
\text { 및 } \\
\text { 허가 }\end{array}$ & $\begin{array}{l}\text { BUS0_BATT:LACK sends (TYPe: REQ) @tX:131 } \\
\text { \#\# (BUSO) REQUEST EXCHANGE TO SERVER! @131sec } \\
\text { SERVER_BMAN: FREE receives (TYPe: REQ) @in:131 } \\
\text { SERVER_BMAN OutPut } \\
\text { SERVER_BMAN:CALC sends (TYPe: PERM) (Bid:0, Qid:0) } \\
\text { \&\& (SERVER) GIVE A PERMISSION! (BUSO } \rightarrow \text { SWAP0) }\end{array}$ \\
\hline 1 & $\vdots$ \\
\hline $\begin{array}{c}\text { 배터리 } \\
\text { 교체소 } \\
\text { 도착 }\end{array}$ & $\begin{array}{l}\text { \# (BUS0) ARRIVE QCMO @212sec } \\
\text { QDIS: IDLE receives (TYPe: ARR) @in: } 212 \\
\text { QDIS OutPut } \\
\text { QDIS: SEND sends (TYpe: ARR) @out_0:212 } \\
\text { MCU0: FREE receives (TYPe: ARR) @in: } 212\end{array}$ \\
\hline 1 & $\vdots$ \\
\hline $\begin{array}{c}\text { 교체소 } \\
\text { 진입 허가 }\end{array}$ & $\begin{array}{l}\text { MCU0: FREE receives (TYPe: ARR) @in: } 212 \\
\text { MCU0 OutPut } \\
\text { MCU0: REPLY sends DONE @done: } 212 \\
\text { MCU0: REPLY (TYPe: CALL) @out_B: } 212 \\
\text { \#\#(BUSO) ENTER QCMO @212sec }\end{array}$ \\
\hline 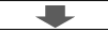 & $\begin{array}{c}\vdots \\
\end{array}$ \\
\hline $\begin{array}{c}\text { 배터리 } \\
\text { 교체 시작 }\end{array}$ & $\begin{array}{l}\text { BUS0_BATT:_IN sends (TYPe: START) @tx: } 213 \\
\text { MCU0:FREE receives (TYPe: START) @in: } 213 \\
\text { MCU0 OutPut } \\
\text { MCU0: CHANGE (TYpe: UNRNOWN) @out_B: } 213 \\
\text { MCU0: CHANGE (TYpe: DONE) @done: } 213 \\
\text { ARM0: IDLE receives (TYpe: UNRNOWN) erun: } 213\end{array}$ \\
\hline 5 & \\
\hline $\begin{array}{c}\text { 배터리 } \\
\text { 교체 완료 } \\
\text { 및 } \\
\text { 버스출고 }\end{array}$ & $\begin{array}{l}\text { ARM0 OutPut } \\
\text { ARM0: CHANGE sends (TYPe: EEND) @off: } 223 \\
\text { MCU0: FREE receives (TYPe: EEND) @in: } 223 \\
\text { MCU0 OutPut } \\
\text { MCU0: EDONE (TYpe: END) @out_B: } 223 \\
\text { MCU0: EDONE (TYPe: QSTAT) @out_S: } 223 \\
\text { MCU0: EDONE (TYPe: DONE) @done: } 223 \\
\text { MCU0: EDONE (TYPe: DONE) @on: } 223 \\
\text { \# (BUSO) EXCHANGE COMPLETE AT QCMO @223se }\end{array}$ \\
\hline
\end{tabular}

Fig. 17. Simulation logs of battery exchange scheduling service 
위치정보를 갱신하고 주기적으로 내부사건을 처리해서 출력 을 발생시키며 이것들은 STOP 모델들의 입력포트로 전달된 다. STOP 모델은 UT의 동작을 모델링한 것이다. 즉, 서버 에서 브로드캐스팅한 데이터 중에 자신에 해당하는 노선정 보만을 추출하여 곧 도착할 버스의 정보를 표출하는 동작을 모델링한 것이다. STOP 모델은 LMAN 모델에 의해 외부사 건이 들어올 때마다 위치정보를 저장하고 표출한다. 지면 관계상 3.3절의 배터리 교체 작업 스케줄링 서비스에 대한 모델링 소개는 생략한다.

\section{4 시뮬레이션}

제안된 시스템의 기능을 검증하기 위해 모델링된 결과를 $\mathrm{DEVSim}^{++}$[8]을 이용하여 시뮬레이션 하였다. $\mathrm{DEVSim}^{++}$는 $\mathrm{DEVS}$ 형식론의 추상화 시뮬레이터 알고리즘을 $\mathrm{C}++$ 언어로 구현한 것이다. 시뮬레이션 결과 본 논문에서 제안된 배터 리 자동 교체형 전기버스 운영시스템이 두 가지 주요 기능 들을 충실하게 수행하는 것을 Fig. 16,17 과 같은 로그 메시 지를 통해 확인할 수 있었다.

\section{5. 결 론}

본 논문에서는 배터리 자동 교체형 전기버스 운영 시스템 을 제안하였다. 제안된 시스템은 서비스 수행에 필요한 통 신량이 많지 않아 통신 속도가 느린 기존 버스정보시스템의 통신 인프라에서도 충분히 구현이 가능하다. 이와 같은 장 점은 새로운 시스템을 도입하였을 때 생기는 새로운 인프라 구축에 대한 부담을 줄여준다. 또한 기존 버스정보시스템의 버스 도착 알림 서비스를 동일하게 제공하여 기존 버스정보 시스템의 편리성을 유지하였다. 여기에 추가로 버스의 배터 리 교체 작업을 스케줄링 해주는 서비스를 제공하여 특정 배터리 교체소에 배터리 교체 작업이 몰리는 현상을 예방하 고자 하였다. 또한 본 논문에서는 제안된 시스템의 구성요 소들을 DEVS 형식론으로 모델링하여 구성요소들의 동작을 구체적으로 분석할 수 있었다. 더불어 모델링한 모델들을 $\mathrm{DEVSim}++$ 을 이용하여 시뮬레이션 하여 제안된 시스템의 주요 기능들을 실험적으로 검증하였다.

그러나 제안된 시스템이 실제로 구현되기 위해서는 추후 에 하위 계층 프로토콜에 대한 구성 및 정형검증이 필요하 며, 배터리 교체작업 스케줄링에 대한 알고리즘 연구가 필 요하다.

\section{Reference}

[1] C. S. Kim and S. H. Lee, "The Impact of Greenhouse Gas Reduction on the Korean Economy and Environment Using Dynamic CGE," The Korean Journal of Agricultural Economics, Vol.45, No.4, pp.169-190, 2004.
[2] J. Y. Ko, W. C. Choi, S. J. Heo, and J. I. Jeong, "Electric Bus Conversion with Replaceable Battery Configuration for a Public Transportation Application," in Proceedings of the KSAE Annual Conference and Exhibition, Daejeon, 2011, pp.2649-2654.

[3] J. Y. Kim, J. Y. Ko, W. C. Choi, and S. J. L, "Battery Swapping Mechanism of Electric Bus for Smart Transportation System," in Proceedings of the KSAE Annual Conference and Exhibition, Goyang, 2012, pp.2331-2337.

[4] Y. W. Lee, "A Study for Communication Mode of Bus Information System," The Korean Society of Industrials Application, Vol.10, No.4, pp.241-248, 2007.

[5] M. Y. Bin, H. B. Kim, and H. K. Han, "A Study on BIS(Bus Information System) Building Strategies and Assessing Their Impacts," Gyeonggi Research Institute, 2004.

[6] W. K. Lee and Y. T. Jung, "The Methods of Establishment about Bus Information System(BIS) at Busan Metropolitan City," Busan Development Institute, 2004.

[7] B. P. Zeigler, H. Praehofer, and T. G. Kim. "Theory of modeling and simulation: Integrating discrete event and continuous complex dynamic systems," 2nd ed., Academic Press, 2000.

[8] T. G. Kim, "DEVSim++ User's Manual : C++ Based Simulation with Hierarchical Modular DEVS Model," Computer Engineering Lab., Dept of Electrical Engineering, KAIST, 1994.

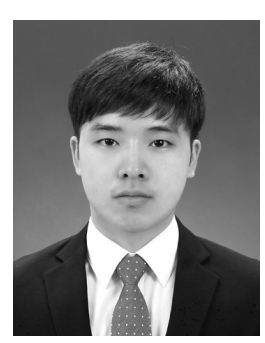

\section{김 한 얼}

e-mail :khu87@naver.com 2012년 국민대학교 전자공학부(학사) 2014년 국민대학교 전자공학과(공학석사) 관심분야: 임베디드 시스템, 시뮬레이션, 운영체제

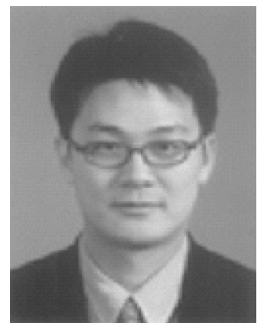

\section{박 준 석}

e-mail : jspark@kookmin.ac.kr

1987년 국민대학교 전자공학과(학사)

1993년 국민대학교 전자공학과(공학석사) 1996년 국민대학교 전자공학과(공학박사) 1998년 현 재 국민대학교 전자공학과 교수 관심분야:DGS, RFIC, $\mathrm{RFID} / \mathrm{USN}$, 자가유지 시스템, 전기자동 차 교통체계, VMS, ITS 


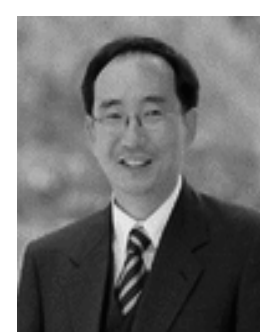

\section{오 하 령}

e-mail : hroh@kookmin.ac.kr

1983년 서울대학교 전기공학과(학사)

1988년 KAIST 전기 및 전자공학과 (공학석사)

1992년 KAIST 전기 및 전자공학과 (공학박사)

1992년 현 재 국민대학교 전자공학부 교수 관심분야: RFID/USN, 임베디드 시스템, 운영체제

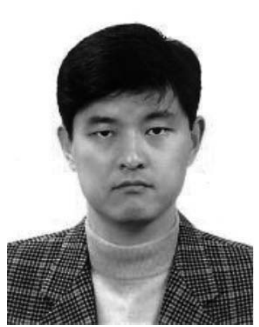

성 영 락

e-mail : yeong@kookmin.ac.kr 1989년 한양대학교 전자공학과(학사)

1991년 KAIST 전기 및 전자공학과 (공학석사)

1995년 KAIST 전기 및 전자공학과 (공학박사)

1995년 1996년 KAIST 위촉연구원

1996년 현 재 국민대학교 전자공학부 교수

관심분야: $\mathrm{RFID} / \mathrm{USN}$, 실시간 시스템, 이산사건 모델링, 시뮬레이션 